\title{
Long-term effect of different annual frequencies of ethylene stimulation on rubber productivity of clone GT 1 of Hevea brasiliensis (Muell. Arg.) in South East of Côte d'Ivoire
}

\author{
Mohamed Sahabane Traoré ${ }^{1,2}$, Moussa Diarrassouba ${ }^{2}$, Koffi Mathurin Okoma ${ }^{3}$, Koulaka \\ Emmanuel Dick ${ }^{2}$, Eric Francis Soumahin ${ }^{1,2}$, Lacina Fanlégué Coulibaly ${ }^{1,2}$, Samuel \\ Obouayeba $^{1}$ \\ ${ }^{1}$ Centre National de Recherche Agronomique (CNRA), Station de Recherche de Bimbresso, \\ Côte d'Ivoire, 01 BP 1536 Abidjan 01, Phone : (225) 234541 76, Fax : (225) 23472122 \\ ${ }^{2}$ Université de Cocody, UFR Biosciences, Laboratoire de Physiologie Végétale, 22 BP 582 \\ Abidjan 22, Côte d'Ivoire, Tel/Fax : (225) 22444473 \\ ${ }^{3}$ Centre National de Recherche Agronomique (CNRA), Laboratoire Central de \\ Biotechnologie, 01 BP 1740 Abidjan 01, Côte d'Ivoire, Phone : (225) 234724 24, Fax : (225) \\ 23472411 \\ Corresponding author: TRAORE Mohamed Sahabane, Phone: (225) 234541 76, Email : \\ msahabane@yahoo.fr \\ ABSTRACT
}

\begin{abstract}
The surstimulation in exploitation of Hevea brasiliensis clones leads to a high rate of unproductive trees due to tapping panel dryness (TPD), and a drop of yield due to the unknown of their yield potential. This study was conducted during 9 years in the south eastern Côte d'Ivoire on clone GT1 of Hevea brasiliensis to determine the best regime of hormonal stimulation that can allow it to express its rubber production potentialities. The GT 1 is a clone at moderate metabolic activity, little susceptibility to wind breakage and TPD, it's the most widely planted clone in Côte d'Ivoire. The plot was planted at the density of 510 trees/ha $(7 \mathrm{~m} \times 2.80 \mathrm{~m})$ according to a "one-tree plot design". Thirteen three trees per treatment were chosen in total randomization. Trees were tapped in S/2 d4 and stimulated with Ethephon $2.5 \%$ at varied frequencies from 0 to 78 per year. The measured parameters included rubber yield, radial vegetative growth, physiological profile and the sensitivity to tapping panel dryness of trees. The results showed that 4 hormonal stimulations per year are sufficient to this clone, to reach its higher yield in tapping in $S / 2 \mathrm{~d} 4$ without causing prejudices on the vegetative growth, physiological profile and sensitivity of tapping panel dryness. This study can be lied down at other region of Côte d'Ivoire for the improvement of the exploitation of clones and optimize yield of plantations.
\end{abstract}

Key words: Hevea brasiliensis, GT 1 clone, tapping, stimulation, yield potential, growth, physiological profile, tapping panel dryness, Côte d'Ivoire.

\section{INTRODUCTION}

Latex is extracted from rubber trees by a multi-annual tapping system that may last 15 to 30 years. In Côte d'Ivoire, farmers use a half-spiral downward system $(\mathrm{S} / 2)$ with a frequency of 3 tapping per week (d3 $6 \mathrm{~d} / 7$ ), or 3 tapping every 2 weeks (d4 $6 \mathrm{~d} / 7$ ). A minimum of 9 years of downward tapping may be followed by a quarter-spiral (S/4) upward system (Gohet et al., 1991). Application of 2-chloroethylphosphonic acid, an ethylene generator, on tapping panel increased the yield (Abraham et al., 1968; d'Auzac and Ribaillier, 1969). Ethylene increases the duration of latex flow after tapping and activates the latex cell metabolism (Buttery and Boatman, 1967; Lustinec et al., 1965; Pakianathan et al., 1976; Jacob et al., 1989; d'Auzac et al., 1997). Today, yield stimulation offers opportunities for reducing tapping frequency and increase of land or labour productivity (Sivakumaran et al., 1983; Sivakumaran and Chong, 1994; Eschbach and Banchi, 1985; Gohet et al., 1991; Lukman, 1995; Gohet, 1996; Thanh et al., 1996 and 1998; Vijayakumar et al., 2000 and 2001). Clone tapping system has been backed by deep researches focusing on the physiology of laticifer tissues; this has resulted in a concept of clone yield 
potential linked to a clonal metabolic typology (Commère et al., 1991; Gohet et al., 1995; Gohet, 1996). According to the clonal functioning typology, when opened for tapping, some clones favour the latex regeneration pathway, but through competition with tree growth (Serres et al., 1988; Jacob et al., 1989; Gohet et al.,1995 and 1996). The surstimulation of trees leads to a high rate of unproductive trees and a drop of yield. In order to make tapping system recommendations there is a need to know the effect of stimulation on latex synthesis, tree growth and yield. Clonal yield potential may depend on these features. The effects of ethylene stimulation in yield potential of clone GT 1 by varying the hormonal stimulation frequency will be studied. Rubber yield, the physiological status, the growth of the trees and the sensitivity of TPD, will be measured. The trials were set up at the Research Station of CNRA of Bimbresso in Côte d'Ivoire.

\section{MATERIALS AND METHODS}

Plant material: The experiment focused on the clone GT1 of Hevea brasiliensis planted in 1981. The trees which started to be tapped in 1986 at $1.20 \mathrm{~m}$ from the ground, were exploited in half-spiral downward system with a frequency of 3 tapping every 2 weeks $(\mathrm{S} / 2 \mathrm{~d} 4 \mathrm{6d} / 7)$. The GT 1 is a clone at moderate metabolic activity, little susceptibility to wind breakage and TPD. It's the most widely planted clone in Côte d'Ivoire.

\section{METHODS}

Study site: The experiment was carried out at Centre National de Recherche Agronomique (CNRA, research station of Bimbresso) in south eastern of Côte d'Ivoire. This region is characterized by a subequatorial climate with two rainy seasons and two dry seasons. The soils are ferralitic derived from tertiary sand (Keli et al., 1992).

Statistical design: The experimental design was a "one-tree plot design" with 33 trees per treatment or 33 repetitions and total randomization of all the trees in a plot. Trees of equal size were selected at the beginning of trial. The plot was planted with clone GT1 at the density of 510 trees/ha $(7 \mathrm{~m} \times 2.80 \mathrm{~m})$ according to a "one-tree plot design" and trees were opened at $1.20 \mathrm{~m}$ from the ground on virgin bark of base panel (BO-1).

Treatments or tapping systems: The trees were tapped fortnightly in a half spiral downward system (S/2 d4 6d/7. 12m/12. ET2.5 \%). One gram of a mixture of palm oil containing Ethephon at $2.5 \%$ (active ingredient) was applied on the tapping cut. There is 8 treatments which correspond to a number of hormonal stimulations applied $(0,2,4,8,13,26$, 39 , and 78 per year) and untapped trees.

Listing of differents treatments (Lukman, 1983; Vijayakumar, 2008 and Vijayakumar et al., 2009).

\section{Measurements and Data Processing}

Rubber production: Each tree latex yield was measured by weighing the cumulative coagulated rubber every four weeks. Total solid content was measured from a bulk sample taken in each treatment in order to convert fresh weights into grams of dry rubber per tree. Latex yield was expressed in kilograms per hectare $\left(\mathrm{kg} \cdot \mathrm{ha}^{-1}\right)$, grams per tree $\left(\mathrm{g} \cdot \mathrm{t}^{-1}\right)$ and grams per tapping per tree $\left(g \cdot \mathrm{t}^{-1} \cdot \mathrm{t}^{-1}\right)$.

Radial vegetative growth: The annual growth in centimeter $(\mathrm{cm})$ and girth increment in centimeter per year (cm.year ${ }^{-1}$ ) of the trees was assessed every year at $1.70 \mathrm{~m}$ from the ground, during the 9 years of the experiment.

Latex analysis: The latex diagnosis per treatment was carried out every year between September and November. The biochemical parameters such as dry rubber content (DRC), sucrose (Suc), inorganic phosphorus (Pi) and thiol contents (RSH) were evaluated. Sucrose (Suc), inorganic phosphorus (Pi) and thiol (RSH) contents were measured on the clear serum called TCA-serum (trichloroacetic acid) that obtained after latex acid coagulation, respectively, by the Ashwell anthrone method (1957), the Taussky and Shorr molybdate ammonium method (1953) and the Boyne and Ellman acid dinitro-dithio-dibenzoic method (1972). The results are stated in millimole per litre of latex $\left(\mathrm{mmol} . \mathrm{I}^{-1}\right)$. DRC represented the percentage of dry rubber in latex, a latex sample was weighed before and after drying in oven at $80{ }^{\circ} \mathrm{C}$ for $24 \mathrm{~h}$. Sucrose reflected the balance between sucrose consumption by the laticifer (for energy production and rubber biosynthesis) and sucrose loading from the apoplast into the laticifer. Pi indicated the level of availabled energy in the metabolic activity of the laticifer. RSH indicated the level of lutoids protection and the stability of latex. Sucrose, Pi and RSH contents were expressed in millimoles per litre of latex $\left(\mathrm{mmol} . \mathrm{I}^{-1}\right)$.

Visual estimation of the tapping panel dryness: On certain trees, during tapping, the flow of latex is abnormally weak or even nonexistent; a more or less important part of the cut does not produce latex. It's a symptom of tapping panel dryness (TPD). In addition, 
TPD was assessed by visual estimation of dry-cut length on each tree which enables to report on the evolution of the symptom. On that respect, the trees tapped were rated from 0 to 6 in proportion to the progress of the disease according to the code below.

0 : healthy cut, normal flow all along the tapping cut...

6: completely dry cut.

Statistically analysis: A one-way ANOVA was done to compare the treatments of ethylene stimulation, as it is known there is interaction between clone and ethylene's stimulation (Gohet, 1996; Gohet et al., 1996). All differences were tested for statistical significance using the Student-Newman-Keuls test with an alpha threshold of 0.05 . Statistical analyses of latex yield and biochemical parameters were performed using XL-STAT software.

\section{RESULTS}

Rubber yield: The average yield for clone GT 1 over 9 years of tapping depending on the number of stimulations (Table 1). Yield was expressed in g. $\mathrm{t}^{-1} \cdot \mathrm{t}^{-1}$, g.t $\mathrm{t}^{-1}$ and $\mathrm{kg} \cdot \mathrm{ha}^{-1}$. There is a significant difference between the values of rubber yield in different treatments. The highest yield was obtained with 4 stimulations. Yield increases from 0 to 4 stimulations per year and reaches the most level with 4 annual stimulations $(1598 \mathrm{~kg} / \mathrm{ha})$. Over this frequency of ethylene stimulation, rubber yield decreased with the number of annual stimulation (8, 13, 26, 39 and 78 stimulations per year). The trees of treatements stimulated respectively $0,2,4,8,13$ times (respectively treatment 2 up to 6 ) had a values statisticaly equivalents and superiors to values of trees of treatments stimulated 26, 39 and 78 times (respectively treatment 7 up to 9 ). There is a difference between traitments and each other (from treatments 7 to 9 ).

Radial vegetative growth: The variation in girth increment (cm.year ${ }^{-1}$ ) during 9 years of tapping depending on the number of stimulations (Table 2). Trees growth and girth increment are affected by stimulation. There is a significant difference between the girth increments of differents treatments. Three situations were presented:

- Firstly, the growth of untapped and unstimulated trees (treatment 1) was superior than that of tapped trees treatments (treatments 2 up to 9 or $0,2,4,8$, 13, 26, 39 and 78 stimulations per year).

- Secondly, the growth of tapped trees and unstimulated, were superior than that of the stimulated treatments $(2,4,8,13,26,39$ and 78 stimulations per year).

- Thirdly, between stimulated treatments, the girth increment decreased with annual stimulation number $(2,4,8,13,26,39$ and 78 stimulations per year).

Physiological parameters: Comparatively in the unstimulated trees, the increase of annual stimulation $(2,4,8,13,26,39$ and 78$)$ in $S / 2$ d4 of GT 1 clone had not incidence on the rate of dry rubber content (Table 3). Sucrose, inorganic phosphorus (Table 4) and thiol contents (Tables 5) influenced by this augmentation. There is a rise of sucrose content and a fall of inorganic phosphorus and thiol contents.

Dry rubber content: The dry rubber content (DRC) during 9 years of tapping is not linked to the number of stimulations (Table 3). The rates of DRC content were equivalent to the DRC standard values of GT1. There is not a significant difference between the values of DRC of differents treatments and these values were increased with the increase of annual stimulation. Sucrose: The evolution of sucrose content (Suc) depending on the number of stimulations (Table 4). Latex sucrose content was sensitive to the stimulation frequency; the high stimulations frequencies inhibit to the sucrose content for clone GT 1. At beginning of the experimentation, the trees unstimulated (treatment 2) had a highest sucrose content followed by the trees stimulated 2 times (treatment 3). Others trees of others treatments (treatments 4 up to 9) had a lowest sucrose content and were statisticaly identical. However, at the end of the experimentation, the treatment 4 (trees stimulated 4 times) had a highest value. Even so, sucrose content increased from 0 to 8 stimulations per year (trees of treatments 2 up to 5 stimulated respectively $0,2,4$ and 8 times) and was much lower beyond just 8 stimulations (treatment 6 up to 9 stimulated respectively 13, 26, 39 and 78 times). According statistical analyse, there is difference between treatments and each other.

Inorganic phosphorus: The evolution of inorganic phosphorus content $(\mathrm{Pi})$ depending on the number of stimulations (Table 5). There is a significant difference between the values of $\mathrm{Pi}$ content of differents treatments at the beginning of experimentation. But, at the end of treatments experimentation, treatments are identical. In addition, $\mathrm{Pi}$ content was lower for all stimulated treatements compartive to the Pi standard values of GT1, except for the treatment 5 (8 stimulations). 
Agric. Biol. J. N. Am., 2011, 2(8): 1251-1260

Table 1. Listing of differents treatments (Lukman, 1983 ; Vijayakumar, 2008 et Vijayakumar et al., 2009).

\begin{tabular}{|c|c|c|}
\hline $\mathbf{N}^{\circ}$ & Tapping systems & Description \\
\hline 1 & Untapped trees & Untapped trees \\
\hline 2 & $\mathrm{~S} / 2 \mathrm{~d} 46 \mathrm{~d} / 712 \mathrm{~m} / 12 . \mathrm{ET} 2.5 \% \mathrm{~Pa} 1(1)$ 0/y & $\begin{array}{l}\text { Half spiral cut tapped downward at four daily frequency, six days in } \\
\text { tapping followed by one day rest, twelve months in twelve; stimulated } \\
\text { with Ethephon of } 2.5 \% \text { active ingredient with } 1 \mathrm{~g} \text { of stimulant applied } \\
\text { on } 1 \mathrm{~cm} \text { band on scraped bark below the tapping cut, } 0 \text { application } \\
\text { per year. }\end{array}$ \\
\hline 3 & $\mathrm{~S} / 2 \mathrm{~d} 46 \mathrm{~d} / 712 \mathrm{~m} / 12 . \mathrm{ET} 2.5 \% \mathrm{~Pa} 1(1) 2 / \mathrm{y}^{*}$ & $\begin{array}{l}\text { Half spiral cut tapped downward at four daily frequency, six days in } \\
\text { tapping followed by one day rest, twelve months in twelve; stimulated } \\
\text { with Ethephon of } 2.5 \% \text { active ingredient with } 1 \mathrm{~g} \text { of stimulant applied } \\
\text { on } 1 \mathrm{~cm} \text { band on scraped bark below the tapping cut, } 2 \text { applications } \\
\text { per year at irregular interval between applications. }\end{array}$ \\
\hline 4 & $\mathrm{~S} / 2 \mathrm{~d} 46 \mathrm{~d} / 712 \mathrm{~m} / 12 . \mathrm{ET} 2.5 \% \mathrm{~Pa} 1(1) 4 / \mathrm{y}^{*}$ & $\begin{array}{l}\text { Half spiral cut tapped downward at four daily frequency, six days in } \\
\text { tapping followed by one day rest, twelve months in twelve; stimulated } \\
\text { with Ethephon of } 2.5 \% \text { active ingredient with } 1 \mathrm{~g} \text { of stimulant applied } \\
\text { on } 1 \mathrm{~cm} \text { band on scraped bark below the tapping cut, } 4 \text { applications } \\
\text { per year at irregular between applications. }\end{array}$ \\
\hline 5 & $\mathrm{~S} / 2 \mathrm{~d} 46 \mathrm{~d} / 712 \mathrm{~m} / 12 . \mathrm{ET} 2.5 \% \mathrm{~Pa} 1(1)$ 8/y (m) & $\begin{array}{l}\text { Half spiral cut tapped downward at four daily frequency, six days in } \\
\text { tapping followed by one day rest, twelve months in twelve; stimulated } \\
\text { with Ethephon of } 2.5 \% \text { active ingredient with } 1 \mathrm{~g} \text { of stimulant applied } \\
\text { on } 1 \mathrm{~cm} \text { band on scraped bark below the tapping cut, } 8 \text { applications } \\
\text { per year at interval of } 1 \text { month between applications. }\end{array}$ \\
\hline 6 & $\mathrm{~S} / 2 \mathrm{~d} 46 \mathrm{~d} / 712 \mathrm{~m} / 12 . \mathrm{ET} 2.5 \% \mathrm{~Pa} 1(1)$ 13/y(3w) & $\begin{array}{l}\text { Half spiral cut tapped downward at four daily frequency, six days in } \\
\text { tapping followed by one day rest, twelve months in twelve; stimulated } \\
\text { with Ethephon of } 2.5 \% \text { active ingredient with } 1 \mathrm{~g} \text { of stimulant applied } \\
\text { on } 1 \mathrm{~cm} \text { band on scraped bark below the tapping cut, } 13 \text { applications } \\
\text { per year at interval of } 3 \text { weeks between applications. }\end{array}$ \\
\hline 7 & $\mathrm{~S} / 2 \mathrm{~d} 46 \mathrm{~d} / 712 \mathrm{~m} / 12 . \mathrm{ET} 2.5 \% \operatorname{Pa} 1(1)$ 26/y(2w) & $\begin{array}{l}\text { Half spiral cut tapped downward at four daily frequency, six days in } \\
\text { tapping followed by one day rest, twelve months in twelve; stimulated } \\
\text { with Ethephon of } 2.5 \% \text { active ingredient with } 1 \mathrm{~g} \text { of stimulant applied } \\
\text { on } 1 \mathrm{~cm} \text { band on scraped bark below the tapping cut, } 26 \text { applications } \\
\text { per year at interval of } 2 \text { weeks between applications. }\end{array}$ \\
\hline 8 & $\mathrm{~S} / 2 \mathrm{~d} 4$ 6d/7 $12 \mathrm{~m} / 12 . \mathrm{ET} 2.5 \% \mathrm{~Pa} 1(1) 39 / \mathrm{y}(\mathrm{w})$ & $\begin{array}{l}\text { Half spiral cut tapped downward at four daily frequency, six days in } \\
\text { tapping followed by one day rest, twelve months in twelve; stimulated } \\
\text { with Ethephon of } 2.5 \% \text { active ingredient with } 1 \mathrm{~g} \text { of stimulant applied } \\
\text { on } 1 \mathrm{~cm} \text { band on scraped bark below the tapping cut, } 39 \text { applications } \\
\text { per year at interval of } 1 \text { week between applications. }\end{array}$ \\
\hline 9 & $\mathrm{~S} / 2 \mathrm{~d} 46 \mathrm{~d} / 712 \mathrm{~m} / 12 . \mathrm{ET} 2.5 \% \mathrm{~Pa} 1(1)$ 78/y(4d) & $\begin{array}{l}\text { Half spiral cut tapped downward at four daily frequency, six days in } \\
\text { tapping followed by one day rest, twelve months in twelve; stimulated } \\
\text { with Ethephon of } 2.5 \% \text { active ingredient with } 1 \mathrm{~g} \text { of stimulant applied } \\
\text { on } 1 \mathrm{~cm} \text { band on scraped bark below the tapping cut, } 0 \text { application } \\
\text { per year at interval of } 4 \text { days between applications. }\end{array}$ \\
\hline
\end{tabular}


Table 2. Average yield $\left(g \cdot \mathrm{t}^{-1} \cdot \mathrm{t}^{-1}, \mathrm{~g} \cdot \mathrm{t}^{-1}\right.$ and $\left.\mathrm{kg} \cdot \mathrm{ha} \mathrm{a}^{-1}\right)$ for clone GT 1 during 9 years of tapping depending on the number of stimulations $(\mathrm{n} / \mathrm{y})$. According to the ANOVA, different letters in the column indicate a not significant difference between Ethephon stimulation frequency at $p<0.05$ (test of Newan-Keuls)

\begin{tabular}{|c|c|c|c|}
\hline \multirow{2}{*}{$\begin{array}{c}\text { Treatments } \\
\text { S/2 d4 6d/7 } 12 \text { m/12. } \\
\text { ET2.5 \% Pa 1(1) }\end{array}$} & \multicolumn{3}{|c|}{ Production } \\
\hline & $g \cdot t^{-1} \cdot t^{-1}$ & g. $\mathrm{t}^{-1}$ & Kg.ha ${ }^{-1}$ \\
\hline 2. $0 / y$ & $49 \mathrm{a}$ & $3856 a$ & $1543 a$ \\
\hline 3. $2 / y$ & $50 a$ & $3909 a$ & $1564 \mathrm{a}$ \\
\hline 4. $4 / y$ & $51 \mathrm{a}$ & 3996 a & $1598 \mathrm{a}$ \\
\hline $5.8 / y$ & $46 a b$ & $3604 a b$ & $1442 \mathrm{ab}$ \\
\hline $6.13 / y$ & $46 a b$ & $3555 a b$ & $1422 \mathrm{ab}$ \\
\hline $7.26 / y$ & $43 \mathrm{~b}$ & $3337 \mathrm{~b}$ & $1335 \mathrm{~b}$ \\
\hline 8. $39 / y$ & $37 \mathrm{c}$ & $2875 c$ & $1150 \mathrm{c}$ \\
\hline $9.78 / y$ & $32 \mathrm{~d}$ & $2484 \mathrm{~d}$ & $994 \mathrm{~d}$ \\
\hline
\end{tabular}

Table 3. Variation in girth increment (Inc (cm.year $\left.{ }^{-1}\right)$ ) during 9 years of tapping depending on the number of stimulations ( $\mathrm{n} / \mathrm{y})$. According to the ANOVA, different letters in the column indicate a significant difference in Ethephon stimulation frequency at $p<0.05$ (test of Newan-Keuls)

\begin{tabular}{|c|c|}
\hline $\begin{array}{c}\text { Treatments } \\
\text { S/2 d4 6d/7 } 12 \mathrm{~m} / 12 . \\
\text { ET2.5\% Pa 1(1) }\end{array}$ & Girth increment $\left(\mathrm{cm}^{\text {year }}{ }^{-1}\right)$ \\
\hline 1. Untapped & $5,59 \mathrm{a}$ \\
\hline $2.0 / \mathrm{y}$ & $3,02 \mathrm{~b}$ \\
\hline $3.2 / \mathrm{y}$ & $2,56 \mathrm{c}$ \\
\hline $4.4 / \mathrm{y}$ & $2,29 \mathrm{~cd}$ \\
\hline $5.8 / \mathrm{y}$ & $2,21 \mathrm{~cd}$ \\
\hline $6.13 / \mathrm{y}$ & $1,95 \mathrm{de}$ \\
\hline $7.26 / \mathrm{y}$ & $1,82 \mathrm{def}$ \\
\hline $8.39 / \mathrm{y}$ & $1,53 \mathrm{ef}$ \\
\hline $9.78 / \mathrm{y}$ & $1,39 \mathrm{f}$ \\
\hline
\end{tabular}

Table 4. Variation of dry rubber content (DRC (\%)) during 9 years of tapping depending on the number of stimulations $(n / y)$. According to the ANOVA, different letters in the column indicate a significant difference in Ethephon stimulation frequency at $p<0.05$ (test of Newan-Keuls)

\begin{tabular}{|c|c|c|}
\hline Treatments & DRC (\%) \\
\cline { 2 - 3 } $\begin{array}{c}\text { S/2 d4 6d/7 } 12 \mathrm{~m} / 12 . \\
\text { ET2.5\% Pa 1(1) }\end{array}$ & Start & End \\
\hline $2.0 / \mathrm{y}$ & $38,35 \mathrm{a}$ & $45,74 \mathrm{a}$ \\
\hline $3.2 / \mathrm{y}$ & $39,36 \mathrm{a}$ & $45,71 \mathrm{a}$ \\
\hline $4.4 / \mathrm{y}$ & $38,80 \mathrm{a}$ & $44,53 \mathrm{ab}$ \\
\hline $5.8 / \mathrm{y}$ & $38,16 \mathrm{a}$ & $44,39 \mathrm{ab}$ \\
\hline $6.13 / \mathrm{y}$ & $38,49 \mathrm{a}$ & $40,46 \mathrm{~b}$ \\
\hline $7.26 / \mathrm{y}$ & $37,79 \mathrm{a}$ & $36,49 \mathrm{c}$ \\
\hline $8.39 / \mathrm{y}$ & $37,68 \mathrm{a}$ & $35,13 \mathrm{~cd}$ \\
\hline $9.78 / \mathrm{y}$ & $37,64 \mathrm{a}$ & $31,70 \mathrm{~d}$ \\
\hline
\end{tabular}

Thiols: The evolution of thiols content (RSH) depending on the number of stimulations (Table 6).
There is a significant difference between the values of $\mathrm{RSH}$ content of differents treatments at the start 
and the end of the experimentation. In addition, at the end, RSH are lower and fall when the number of stimulation increased.

Tapping panel dryness: The percentages of dry trees (TPD) and dry cuts (DC) (Table 7) indicated:

- at the start, the rates were worthless for all treatments for dry-cut lenght and dry trees,

- at the end of experimentation, the highest rate of dry-cut lenght (22.1\%) was obtained with the trees of treatment 9 (78 stimulations per year) and the lowest (0\%) with the trees of treatment 2 (unstimulated).

- the highest rate of dry trees (12.1\%), was obtained with the trees of treatment 5 (8 stimulations per year) and the lowest $(0 \%)$ with a trees of treatments 2, 3, 7 and 8 (respectively stimuled $0,6,26$ and 39 times).

There is an increase of the sensitivity of trees susceptibility to tapping panel dryness with the number of hormonal stimulation augmentation.

Table 5. Evolution of sucrose (suc) content (mmol..$^{-1}$ ) during 9 years of tapping depending on the number of stimulations (n/y). According to the ANOVA, different letters in the column indicate a significant difference in Ethephon stimulation frequency at $p<0.05$ (test of Newan-Keuls)

\begin{tabular}{|c|c|c|}
\hline \multirow{2}{*}{$\begin{array}{c}\text { Treatments } \\
\text { S/2 d4 6d/7 12 m/12. } \\
\text { ET2.5\% Pa 1(1) }\end{array}$} & \multicolumn{2}{|c|}{$\begin{array}{c}\text { Suc } \\
\left(\text { mmol. }\left.\right|^{-1}\right)\end{array}$} \\
\cline { 2 - 3 } & Start & End \\
\hline $2.0 / \mathrm{y}$ & $24,71 \mathrm{a}$ & $20,44 \mathrm{ab}$ \\
\hline $3.2 / \mathrm{y}$ & $20,86 \mathrm{~b}$ & $28,28 \mathrm{ab}$ \\
\hline $4.4 / \mathrm{y}$ & $9,59 \mathrm{c}$ & $17,04 \mathrm{~b}$ \\
\hline $5.8 / \mathrm{y}$ & $7,84 \mathrm{c}$ & $9,13 \mathrm{c}$ \\
\hline $6.13 / \mathrm{y}$ & $7,76 \mathrm{c}$ & $8,98 \mathrm{c}$ \\
\hline $7.26 / \mathrm{y}$ & $6,91 \mathrm{c}$ & $8,46 \mathrm{c}$ \\
\hline $8.39 / \mathrm{y}$ & $4,65 \mathrm{c}$ & $6,55 \mathrm{c}$ \\
\hline $9.78 / \mathrm{y}$ & $5,90 \mathrm{c}$ & \\
\hline
\end{tabular}

Table 6. Evolution of inorganic phosphorus (Pi) content (mmol..$\left.^{-1}\right)$ during 9 years of tapping depending on the number of stimulations stimulations ( $n / y)$. According to the ANOVA, different letters in the column indicate a significant difference in Ethephon stimulation frequency at $p<0.05$ (test of Newan-Keuls)

\begin{tabular}{|c|c|c|}
\hline \multirow{2}{*}{$\begin{array}{c}\text { Treatments } \\
\text { S/2 } 146 \mathrm{~d} / 712 \mathrm{~m} / 12 . \\
\mathrm{ET} 2.5 \% \mathrm{~Pa} 1(1)\end{array}$} & Start & End \\
\cline { 2 - 3 } $2.0 / \mathrm{y}$ & $5,85 \mathrm{c}$ & $10,75 \mathrm{a}$ \\
\hline $3.2 / \mathrm{y}$ & $8,44 \mathrm{bc}$ & $9,82 \mathrm{a}$ \\
\hline $4.4 / \mathrm{y}$ & $14,20 \mathrm{a}$ & $9,97 \mathrm{a}$ \\
\hline $5.8 / \mathrm{y}$ & $14,28 \mathrm{a}$ & $10,87 \mathrm{a}$ \\
\hline $6.13 / \mathrm{y}$ & $11,51 \mathrm{ab}$ & $8,82 \mathrm{a}$ \\
\hline $7.26 / \mathrm{y}$ & $13,01 \mathrm{a}$ & $9,07 \mathrm{a}$ \\
\hline $8.39 / \mathrm{y}$ & $13,31 \mathrm{a}$ & $8,49 \mathrm{a}$ \\
\hline $9.78 / \mathrm{y}$ & $13,48 \mathrm{a}$ & $7,61 \mathrm{a}$ \\
\hline
\end{tabular}


Table 7. Evolution of thiol (RSH) content (mmol. ${ }^{-1}$ ) during 9 years of tapping depending on the number of stimulations ( $\mathrm{n} / \mathrm{y})$. According to the ANOVA, different letters in the column indicate a significant difference in Ethephon stimulation frequency at $p<0.05$ (test of Newan-Keuls)

\begin{tabular}{|c|c|c|}
\hline \multirow{2}{*}{$\begin{array}{c}\text { Treatments } \\
\text { S/2 d4 6d/7 12 m/12. } \\
\text { ET2.5\% Pa 1(1) }\end{array}$} & RSH $\left(\mathrm{mmol}^{\left.-{ }^{-1}\right)}\right.$ \\
\cline { 2 - 3 } $2.0 / \mathrm{y}$ & $0,69 \mathrm{ab}$ & End \\
\hline $3.2 / \mathrm{y}$ & $0,73 \mathrm{a}$ & $0,54 \mathrm{a}$ \\
\hline $4.4 / \mathrm{y}$ & $0,75 \mathrm{a}$ & $0,42 \mathrm{~b}$ \\
\hline $5.8 / \mathrm{y}$ & $0,75 \mathrm{a}$ & $0,43 \mathrm{~b}$ \\
\hline $6.13 / \mathrm{y}$ & $0,76 \mathrm{a}$ & $0,32 \mathrm{c}$ \\
\hline $7.26 / \mathrm{y}$ & $0,63 \mathrm{~b}$ & $0,28 \mathrm{c}$ \\
\hline $8.39 / \mathrm{y}$ & $0,69 \mathrm{ab}$ & $0,21 \mathrm{~d}$ \\
\hline $9.78 / \mathrm{y}$ & $0,53 \mathrm{c}$ & $0,16 \mathrm{~d}$ \\
\hline
\end{tabular}

Table 8. Percentages of dry trees (TPD (\%)) and dry cuts (DC) during 9 years of tapping depending on the number of stimulations $(\mathrm{n} / \mathrm{y})$

\begin{tabular}{|c|c|c|c|c|}
\hline \multirow{2}{*}{$\begin{array}{l}\text { Treatments } \\
\mathrm{S} / 2 \mathrm{~d} 46 \mathrm{~d} / 712 \mathrm{~m} / 12 . \\
\mathrm{ET} 2.5 \% \mathrm{~Pa} 1(1)\end{array}$} & \multicolumn{2}{|c|}{ TPD (\%) } & \multicolumn{2}{|c|}{ DC (\%) } \\
\hline & Start & End & Start & End \\
\hline 2. $0 / y$ & 0,0 & 0,0 & 0,0 & 0,0 \\
\hline 3. $2 / y$ & 0,0 & 2,8 & 0,0 & 0,0 \\
\hline 4. $4 / y$ & 0,0 & 7,7 & 0,0 & 6,7 \\
\hline 5. $8 / y$ & 0,0 & 15,5 & 0,0 & 12,1 \\
\hline 6. $13 / y$ & 0,0 & 14,5 & 0,0 & 6,9 \\
\hline 7. $26 / y$ & 0,0 & 6,0 & 0,0 & 0,0 \\
\hline 8. $39 / y$ & 0,0 & 16,5 & 0,0 & 0,0 \\
\hline 9. $78 / y$ & 0,0 & 22,1 & 0,0 & 6,9 \\
\hline
\end{tabular}

\section{DISCUSSION}

Rubber yield: rubber yield increased from 0 to 4 stimulations per year (treatment 2 at 4 ) and reached a maximum with 4 annual stimulations. This increasing of yield with 4 stimulations per year, was due to hormonal stimulation which prolong period of latex flow per activation of laticiferous metabolism to a certain limit (Buttery and Boatman, 1967; Lustinec et al., 1965, Pakianathan et al., 1976; Jacob et al., 1989; d'Auzac et al., 1997), and permit a good regeneration of harvested latex. In addition, this result is in keeping with those of Lacote et al. (2009) on GT 1 at HEVEGO in the west of Côte d'Ivoire. Over this optimum frequency of ethylene stimulation or this limit, yield decreased with the increase of annual stimulation $(8,13,26,39$ and 78 stimulations per year). It account for dysfunctioning of laticiferous system, translating per impossibility of increasing of laticiferous metabolism per hormonal stimulation (Gohet, 1996). Beyond 4 stimulations, there is lowering of yield. This was due to fatigue of trees, its effect of surstimulation.

Radial vegetative growth: Tree growth and rubber production competed strongly (Templeton, 1969; Wycherley, 1976; Sethuraj, 1981; Obouayeba et al., 2002; Obouayeba, 2005). Girth increment of trees of treatment untapped and unstimulated was superior than that of the trees of tapped treatments. And, trees unstimulated had girth increment which was superior than that of the trees of stimulated treatments. This is a fact that the trees exploitation translate the hijack of one fraction of photosynthetics assimilates to affect in general metabolism toward the yield stirring treetrunk reduction of trees exploited in relation to trees not exploited (Gohet, 1996; Paardekooper, 1989; Obouyeba et Boa, 1993; Templeton, 1969; 
Obouayeba et al., 2002; Obouayeba, 2005). Between the trees of stimulated treatments, girth increment decrease because the trees were submitted to important stimulation. This carry along the fatigue of trees due to surexploitation or surstimulation (Jacob et al., 1995).

Physiological profile: Dry rubber content: The highest percentages of dry rubber content eyed at the ending of experiment are accounted for by a good rubber biosynthesis and an efficient regeneration of latex (Milford et al., 1969).

Sucrose: Variation of sucrose content was signified that good supply in sucrose of laticiferous with 0 to 8 stimulations per year and a low supply side 8 stimulations (Prévôt et al., 1986).

Inorganic phosphorus: Inorganic phosphorus content is normal with 0 and 8 stimulations per year. In other cases, contents were inferior to normal (GT $1 \mathrm{Pi}$ standard value). This all about a good availability of laticiferous system energy to treatment not stimulated and this energy variable at stimulated treatments (Jacob et al., 1988).

Thiols: Thiols content decreased when the number of annual stimulation increase because repeated stimulations caused instability of latex colloids. This will carry along to a coagulation of latex and consequently yield decrease (Chrestin, 1984).

Tapping panel dryness: The susceptibility to TPD increased with the number of annual stimulation because stimulated treatments presented the lowest thiol contents. This indicates destabilization of latex lutoids stirring their destruction, being to carry along a coagulation of latex and consequently yield decrease (Chrestin, 1984).

\section{CONCLUSION}

This study showed that 4 annual hormonal stimulations per year are sufficient for clone GT 1 to reach its higher yield in tapping in $S / 2$ d4. This frequency of 4 annual hormonal stimulations gives a highest yield (1598 kg/ha) without causing prejudices on the vegetative growth, physiological profile and health of trees. Exploitation system S/2 d4 6d/7 12 $\mathrm{m} / 12 \mathrm{ET} 2.5 \% \mathrm{~Pa} 1(1)$ 4/y was more satisfactory for a best compromise between rubber yield, radial vegetative growth, physiological profile and sensibility of tapping panel dryness.

It is clearly important to define the hormonal stimulation effects in the exploitation of clones. Ethephon stimulation is now an essential technique for increasing rubber production. This study can be lied down at other region of Côte d'Ivoire, therefore the clones of other metabolic activity, for the improvement of the exploitation of clones (Hevea brasiliensis) and optimize yield of plantations.

\section{ACKNOWLEDGEMENTS}

This study was supported by Centre National de Recherche Agronomique (research station of Bimbresso), Abidjan-Côte d'Ivoire.

\section{REFERENCES}

Abraham, P.D., Wycherley, P.R. and Pakianatan, S.W (1968). Stimulation of latex flow in Hevea brasiliensis by 4 - amino - 3.6 trichloropicolinic acid and 2 chloroethane phosphonic acid. J. Rubber res. Inst. Malaya. $20: 291$ - 305.

Ashwell, G (1957). Colorimetric analysis of sugar. Methods Enzymol. 3 : 73 - 105.

Boyne, A.F. and Ellman, G.L (1972). A methodology for analysis of tissue sulphydrylcomponents. Anal. Biochem., 46 : 639 - 653.

Buttery, B.R. and Boatman S.G (1967). Effects of tapping, wounding and growth regulators on turgor pressure in Hevea brasiliensis. J. Exp. Bot., 18 : 644 - 659.

Chrestin, H (1984). Le compartiment vacuo - Iysosomal (les lutoïdes) du latex d'Hevea brasiliensis, son rôle dans le maintien de l'homéostasie et dans les processus de sénescence des cellules laticifères. Thèse Doct. Etat Sci. Nat., Université Sci. Tech. Languedoc, Montpellier, France, 575 p.

Commère, J., Serres, E. and Lacrotte, R (1991). Yield potential for the clones PB 235 and PB 217 tapped with $1 / 2 \mathrm{~S} d / 46 \mathrm{~d} / 7$ for the first 3 years after opening in the Sout East of Côte d'Ivoire. IRRDB Symposium; 1990/10/06-07; Kunming (CHN), Brickendonbury (GBR): IRRDB, 1991. pp 93 - 102.

Compagnon, P. (1986). Le caoutchouc naturel. Coste R. ed., G.P. Maisonneuve et Larose,

Paris, $595 \mathrm{p}$.

d'Auzac, J., Jacob, J.-L., Prévôt, J.C., Clément, A., Gallois, R., Chrestin, H., Lacote, R., Pujade-Renaud, V., and Gohet, E (1997). The regulation of cis-polyisoprene production (natural rubber) from Hevea brasiliensis. In "Recent Research Developments in Plant Physiology" (S. G. Pandalai, ed.). 1 : 273 - 332.

d'Auzac J. and Ribaillier, D (1969). L'éthylène, un nouveau stimulant de la production de latex chez Hevea brasiliensis. C.R. Acad. Paris, Ser D. 268 : 3046 3049.

Eschbach, J.M. and Banchi, Y (1985). Advantages of Ethrel stimulation in association with reduced tapping 
intensity in the Ivory Cost . Planter (MYS), 1985/12. 61 : 555 - 567.

Gohet, E (1996). La production de latex par Hevea brasiliensis. Relations avec la croissance. Influence des différents facteurs: origine clonale, stimulation hormonale, réserves hydrocarbonées. PhD thesis, Université Montpellier II, France, $343 \mathrm{p}$.

Gohet, E., Prévôt, J.C., Eschbach, J.M., Clément, A., and Jacob, J.L (1996). Clone, growth and stimulation: latex production factors. Plantation Recherche Développement. 3 : 30 - 38.

Gohet, E., Prévot, J.C., Eschbach, J.M., Clément, A., and Jacob, J.L (1995). Hevea latex production: relationship with tree growth, influence of clonal origin and ethrel stimulation. Proceedings of the International Rubber research and Development Board Symposium on Physiology and Molecular Aspects of Breeding of Hevea brasiliensis, Penang, Malaysia, 1995, pp 200 210.

Gohet, E., Lacrotte, R., Obouayeba, S., and Commere, J (1991). Tapping systems recommended in West Africa. Proceedings RRIM Rubber Growers' Conference 1991, pp 235 - 254.

Jacob., Prévôt, J.C., Lacrotte, R. and Eschbach, J.M (1995). Le diagnostic latex. Plantations, recherche, développement. 2 : 34 - 37.

Jacob, J.L., Prévôt, J.C., Roussel, D., Lacrotte, R., Serres, E., d'Auzac, J., Eschbach, J.M., and Omont, H (1989). Yield-limiting factors, latex physiological parameters, latex diagnosis, and clonal typology. In: "Physiology of Rubber Tree Latex" (J. d'Auzac, J.L. Jacob and H. Chrestin, Eds.), CRC Press Inc, Boca Raton, Florida, pp 345 - 403.

Jacob, J.L., Serres, E., Prévôt, J.C., Lacrotte , R., Vidal, A., Eschbach, J.M. and d'Auzac, J (1988). Development of Hevea Latex Diagnosis. Agritrop. 12: 97 - 115.

Keli, J. Z., Obouayeba, S et Zehi, B (1992). Influence de quelques systèmes vivriers sur le comportement des jeunes hévéas en basse Côte d'Ivoire. Systèmes Agricoles en Afrique, 2 (1) : 41 - 48.

Lacote, R., Gabla O., Obouayeba, S., Eschbach, J.M., Rivano, F., Dian, K. and Gohet, E (2009). Long-term effect of ethylene stimulation on the yield of rubber trees is linked to latex cell biochemistry. Field Crops Research, 115 : 94 - 98.

Lukman, H.J.G (1995). To increase the yield of smallholder rubber by application of appropriate exploitation system. Indonesian Journal of Natural Rubber Research. $13: 208$ - 211.

Lukman, H.J.G (1983). Revised international notation for exploitation systems. J. Rubber. Res. Inst. Malaysia, $31,130-140$
Lustinec, J. and Resing, W.L (1965). Methods for delimitation of the flow area by micro -tapping and radio-isotopes. Plant. Bull. Rubber Res. Inst. Malaya. $80: 144-149$.

Milford, G.F.J., Paardekooper, E.C. and Ho, C.Y (1969). Latex vessels plugging, its importance to yield and clonal behaviour. J. Rubb. Res. Inst. Malaya, 21 : 274 282.

Obouayeba, S (2005). Contribution à la détermination de la maturité physiologique de l'écorce pour la mise en saignée d'Hevea brasiliensis Muell. Arg. (euphorbiacée) : normes d'ouverture. Thèse de doctorat Unique, UFR Biosciences, Université de Cocody, Côte d'Ivoire, 225 p.

Obouayeba, S., Boa, D., Aké, S. and Lacrotte, R (2002). Influence of age and girth at opening on growth and productivity of Hevea. Indian Journal of Rubber Research, 15 (1) : 38 - 45.

Obouayeba, S. et Boa, D (1993). Fréquence et repos annuel de saignée d'Hevea brasiliensis, clone PB 235, dans le sud-est de la Côte d'Ivoire. Cahiers Agricultures, 2 (6) : 387 - 393.

Paardekooper, E. C (1989). Exploitation of the rubber tree. In Rubber eds. C C Webster et W J Baulkwill, pp 349 414.

Pakianatan, S.W., Wain, R.L. and Ng, E.K (1976). Studies on displacement area on tapping in mature Hevea trees. Proc. Inst Rubb. Conf., Rubb. Res Inst. Malaysia, ed., Kuala Lumpur, pp 225 - 246.

Prévôt, J. C., Jacob, J.N L., Lacrotte, R., Vidal, A., Serres, E., Eschbach, J. M. and Gigault, J (1986). Physiological parameters of latex from Hevea brasiliensis. Their use in the study of the laticiferous system. Typology of functioning production mechanisms. Effects of stimulation. In : IRRDB physiology and Exploitation Meeting, Hainan, 1986, Pan Yanqing and Lhao Canwen Eds, South China Academy of Tropical Crops of functioning (Hainan), pp $136-157$.

Serres, E., Clément, A., Prévôt, J. C., Jacob, J. L., Commère, J., Lacrotte, R., and Eschbach, J. M (1988). Clonal typology of laticiferous producing vessels in Hevea brasiliensis. In CR. Int. Rubb. Res. Dev. Board, Expl. Physiol Amél. Hevea. J.L. Jacob and J.C. Prévôt, ed., IRCA-CIRAD, Montpellier, pp 231 - 246.

Sivakumaran, S. and Chong, K (1994). Yield stimulation in rubber: current status and improvements for enhanced productivity. Proceedings of the International Planters Conference, 1994, Malaysia, pp 369 - 408.

Sivakumaran, S., Pakianathan, S.W. and Gomez, J.B (1983). Long-term Ethephon stimulation. III. Effect of continuous ethephon stimulation with short-cut panelchanging system. Journal of the Rubber Research Institute of Malaysia. $31: 151$ - 174. 
Sethuraj, M.R (1981). Yield components in Hevea brasiliensis. Plant Cell Environ. $4: 81$ - 83.

Taussky, H.H. and Shorr, E (1953). A micro colorimetric method for the determination of inorganic phosphorus. J. Biol. Chem., $202: 675$ - 685.

Templeton, J.K (1969). Partition of assimilates. J. Rubber Res. Inst. Malaysia. 21 : 259 - 273.

Thanh, D.K., Sivakumaran, S. and Wong, K.C (1998). Influence of judicious methods of stimulation on the long term yield responses of rubber clone RRIM 600 . Proceeding of the International Rubber Research and Development Board Symposium of Natural Rubber (Hevea brasiliensis), (2), Physiology and Exploitation and Crop Protection and Planting Methods, 1997, Ho Chi Mminh City, Vietnam, pp 66 - 70.

Thanh, D.K., Sivakumaran, S. and Wong, K.C (1996). Long term effect of tapping and stimulation frequency on yield performance of rubber clone GT 1. Journal of Natural Rubber Research. 11 : 96 - 107.

Vijayakumar, K.R (2008). Revised international notation for latex production technology. IRRDB Workshop of
Latex Harvesting Technologies, Sungai Buloh, Selangor, 5-8 May 2008, p 20.

Vijayakumar, K.R., Gohet, E., Thomas, K.U., Sumarmadji, X. W., Lakshman, R., Thanh, D.K., Pichit, S., Karunaichamy, K. and Said, M.A.MD (2009). Revised international notation for latex harvest technology. IRRDB Workshop of Latex. Harvesting Technologies, 20 february 2009, $19 \mathrm{p}$.

Vijayakumar, K.R., Thomas, K.U., Rajagopal, R and Karunaichamy, K (2001). Low frequency tapping systems for reductions in cost of production of natural rubber. Planters' Chronicle, 97 (11) : 451 - 454.

Vijayakumar, K.R., Thomas, K.U., and Rajagopal, R (2000). Tapping: In; natural rubber, Agromanagement and Crop Processing. Eds. Georges, P.J. and Jacob, K.C. Rubber Research Institute of India, Kottayam, India, pp 215 - 238.

Wycherley, P.R (1976). Tapping and partition. J. Rubber Res. Inst. Malaysia. 24 : 169 - 194. 